\title{
EKSPLORASI FOLKLOR KAMPUNG PITU NGLANGGERAN (KAJIAN SASTRA DENGAN PENDEKATAN PARIWISATA)
}

\author{
FOLKLORE EXPLORATION OF "KAMPUNG PITU NGLANGGERAN" \\ (LITERATURE STUDY WITH A TOURISM APPROACH)
}

\author{
Dyah Ayu Putri Utami; Ari Kusmiatun
}

Universitas Negeri Yogyakarta

Jalan Colombo Yogyakarta Nomor 1, Daerah Istimewa Yogyakarta, Indonesia

dyahayu.2019@student.uny.ac.id

(Naskah diterima tanggal 22 Februari 2021, direvisi terakhir tanggal 6 Oktober 2021, dan disetujui tanggal 26 November 2021)

DOI: https:/ / doi.org/10.26499/wdprw.v49i2.794

\begin{abstract}
This study includes a qualitative descriptive study that aims to explore the folklore of Kampung Pitu using a tourism literature approach. This approach focuses on the study of the phenomena of literary works, writers, literary festivals, and folklore that make a real contribution to the development of tourism. The data of this research are in the form of sentences in the folklore that developed in Pitu Village. Data collection techniques using interviews and documentation. Data analysis techniques, namely reduction, presentation, and drawing conclusions. The results showed that (1) the folklore in Kampung Pitu consists of the legend of the origin of Kampung Pitu, the myth of Telaga Guyangan, and the myth of Rasulan; (2) each story has an appeal in rules/laws, stories, and rituals; (3) developing folklore has the potential to become a tourist area branding. This branding needs to be supported by the metamorphosis of folklore into theatrical performances, ballet, short films, folklore books, or other narrative forms that can be used as promotions.
\end{abstract}

Keywords: folklore; pitu village; literary studies; tourism approach

\begin{abstract}
Abstrak
Penelitian ini termasuk penelitian deskriptif kualitatif yang bertujuan untuk mengeksplorasi cerita rakyat Kampung Pitu menggunakan pendekatan sastra pariwisata. Pendekatan ini memfokuskan kajian pada fenomena karya sastra, sastrawan, festival sastra, dan cerita rakyat yang memberikan sumbangan nyata dalam perkembangan kepariwisataan. Data penelitian ini berupa kalimat dalam cerita rakyat yang berkembang di Kampung Pitu. Teknik pengumpulan data menggunakan wawancara dan dokumentasi. Teknik analisis data, yaitu reduksi, penyajian, dan penarikan simpulan. Hasil penelitian menunjukkan bahwa (1) cerita rakyat di Kampung Pitu terdiri atas Legenda asal-usul Kampung Pitu, mite Telaga Guyangan, dan mite Rasulan; (2) masing-masing cerita memiliki daya tarik dalam aturan/hukum, cerita, dan ritual; (3) cerita rakyat yang berkembang berpotensi untuk menjadi branding kawasan wisata. Branding ini perlu didukung oleh metamorfosis cerita rakyat menjadi pertunjukkan teater, sendratari, film pendek, buku cerita rakyat, atau bentuk narasi lain yang dapat digunakan sebagai promosi.
\end{abstract}

Kata-kata kunci: folklore; kampung pitu; kajian sastra; pendekatan pariwisata 


\section{Pendahuluan}

Kemajuan pariwisata Indonesia dipengaruhi oleh beberapa hal, salah satunya kontribusi sastra. Satu setengah dekade terakhir, kontribusi sastra dalam dunia pariwisata terasa semakin nyata. Pariwisata dan sastra membentuk simbiosis mutualisme, pariwisata menjadi inspirasi pencipataan karya sastra, sebaliknya sastra memberi kontribusi untuk promosi pariwisata (Ironside \& Massie 2020: 1-2; Putra 2019: 173).

Festival sastra, setting suatu karya sastra, filmisasi karya sastra, dan panggalian folklor sebagai branding destinasi wisata menjadi wujud nyata sumbangsih sastra untuk pariwisata Indonesia (Putra 2019: 173). Kontribusi sastra untuk dunia pariwisata, misalnya terlihat dari Ubud Writers and Readers Festival (UWRF) yang dilaksanakan setiap tahun. Setting novel Laskar Pelangi (2005) yang menjadi terkenal dan sudah diadaptasi menjadi film; novel dan film Elizabeth Gilbert Eat Pray Love (2006 \& 2010) yang membantu peningkatan promosi pariwisata Ubud; dan monu-men menara Van Der Wijk di Pantura yang populer karena novel Tenggelamnya Kapan Van Der Wijk's karya Buya Hamka (Putra, 2019: 173-174; Taufiq \& Siswanto, 2019: 169170).

Country branding "Wonderful Indonesia" melesat menjadi rangking 47 dunia pada tahun 2015. Indonesia unggul dari country branding "Truly Asia Malaysia" di ranking 96 dan country branding "Amazing Thailand" di ranking 83. Artinya, "Wonderful Indonesia" berhasil membawa pariwisata Indonesia ke level dunia. Keragaman budaya yang dimiliki oleh ribuan suku menjadi salah satu keunikan Indonesia. Setiap suku menawarkan ragam agama, adat, budaya, dan kondisi sosial yang berbeda sehingga menarik untuk disimak para wisatawan. Oleh karena itu, pelaku pariwisata perlu melakukan kajian lokasi wisata berdasarkan warisan budaya berupa folklor, khususnya yang berdasar mitos dan legenda daerah setempat (Amanat 2019: 67-68; Ironside \& Massie 2020: 2; Putra 2019b: 174).

Folklor ialah wujud kebudayaan tradisional sekelompok masyarakat yang diwariskan secara turun-temurun secara lisan (Bascom 1965: 4; Harsono 2017: 1-2; Ironside \& Massie 2020: 2). Jenis folklor terdiri atas legenda, musik, sejarah lisan, pepatah, lelucon, takhayul, dongeng, dan adat tradisi (Amanat 2019: 69-70). Folklor yang sering menjadi objek kajian penelitian ialah cerita prosa rakyat atau yang biasa disebut cerita rakyat. Cerita rakyat dibagi menjadi tiga golongan, yaitu mite (myth), legenda (legend), dan dongeng (folktale) (Amanat 2019; Bascom 1965: 3-5; Efirson 2017: 2). Banyak cerita rakyat yang menjadi landasan pengembangan lokasi wisata Indonesia (Amanat 2019: 66-67; Suyasa 2019: 527-528). Salah satu objek wisata yang berhasil karena pemberdayaan warisan folklor ialah pantai Air Manis di Sumatera Barat. Cerita rakyat Si Malin Kundang yang berhasil mendongkrak popularitas destinasi wisata ini (Amanat 2019: 67). Selain itu, ada pula folklor cerita rakyat Putri Mandalika yang menjadi kawasan wisata The Mandalika Resort di Lombok, mitos Putri Naga di Pulau Komodo, legenda Tanjung Lesung di Banten, mitos Raja Ampat di Papua, dan cerita rakyat Siti Nurbaya di Padang (Endriani 2015: 43-56; Putra 2019: 174).

Beberapa tahun terakhir, sepuluh destinasi wisata prioritas sedang dikembangkan pemerintah Indonesia. Pengembangan ini diharapkan dapat menarik turis asing. Destinasi yang dikembangkan meliputi Danau Toba (Sumatera Utara), Borobudur (Jawa Tengah), Mandalika (NTB), Bromo Tengger Semeru (Jawa Timur), Labuan Bajo (NTT), Tanjung Kelayang (Bangka Belitung), Kepulauan Seribu (DKI Jakarta), Tanjung Lesung (Banten), Moratai (Maluku Utara) (Agmasari 2019; Amanat, 2019: 66). 
Sayangnya, jumlah tersebut dinilai kurang berimbang dibandingkan dengan potensi pariwisata yang tersembunyi di berbagai wilayah. Berdasarkan data Badan Pusat Statistik (2019), DIY termasuk dalam sepuluh provinsi yang memiliki jumlah perjalanan wisatawan terbanyak. Dinas Pariwisata DIY mencatat jumlah wisatawan yang berkunjung pada tahun 2019 mencapai 28.324.394 orang. Jumlah wisatawan tersebut menyebar di tiap kabupaten/kota di DIY yang menyuguhkan kekhasan objek wisata alam, budaya, wisata buatan, dan kampung wisata (Dinas Pariwisata DIY 2019).

Wilayah kabupaten yang terkenal dengan ciri wisata alam dan pantai adalah Kabupaten Gunungkidul. Salah satu primadona destinasi wisata di kabupaten tersebut, yaitu kawasan ekowisata Gunung Api Purba Nglanggeran, Patuk. Semenjak lagu Didi Kempot Banyu Langit populer di kalangan masyarakat nasional, wisatawan yang datang semakin bertambah. Lirik lagu Banyu Langit membawa serta nama Nglanggeran, "Ademe gunung merapi purba. Melu krungu swaramu ngomongke apa. Ademe gunung merapi purba. Sing ning Nglanggran, Wonosari, Jogjakarta". Lirik ini cukup menggambarkan suasana objek wisata sehingga pendengar tergugah untuk melihat secara langsung (Adhi 2019; Hidayat 2019; Yuwono 2019).

Kawasan Gunung Api Purba Nglanggeran memiliki pesona panorama alam pegunungan dan pedesaan. Sekitar 60 juta tahun lalu, gunung ini merupakan gunung berapi aktif yang terbentuk dari gunung api dasar laut yang terangkat ke daratan. Bebatuan besar yang menjulang tinggi menjadi jalur pendakian ke Puncak Gunung Gedhe dengan ketinggian 700 meter dari permukaan laut (Dinas Pariwisata Gunungkidul 2020).

Ada pula cerita rakyat yang berkembang di wilayah itu. Konon, Bukit Nglanggeran menjadi tempat hukuman warga yang meru- sak wayang. Nama tempat Nglanggeran sendiri berasal dari kata nglanggar yang berarti 'melanggar'. Ratusan tahun lalu, para warga mengundang dalang untuk menggelar pertunjukkan wayang sebagai ungkapan syukur atas hasil panen yang melimpah. Saat itu, ada beberapa warga yang mencoba merusak wayang milik dalang. Sang dalang yang murka mengutuk perusak wayang menjadi sosok wayang dan dibuang ke puncak bukit (Dinas Pariwisata Gunungkidul 2020). Sayangnya, cerita rakyat tentang Gunung Api Purba Nglanggeran ini belum dioptimalkan untuk menarik wisatawan.

Tiga wisata pilihan di kawasan ekowisata Nglanggeran, yaitu Gunung Api Purba, Embung Nglanggeran, dan Kampung Pitu. Destinasi wisata Kampung Pitu baru dibuka sejak akhir 2019 lalu (Dinas Pariwisata DIY 2020). Daya tarik destinasi wisata ini ialah aturan jumlah kepala keluarga yang tinggal di kampung ini. Pasalnya, sejak zaman dahulu Kampung Pitu hanya boleh dihuni oleh tujuh kepala keluarga. Oleh karena itu, pemerintah setempat memutuskan untuk membu-ka kawasan ini sebagai objek wisata. Objek wisata Kampung Pitu masih terus dikembangkan oleh pemerintah sehingga perlu kajian dari berbagai bidang. Mengingat cerita rakyat dan potensi wisata yang ada, permasalahan ini dapat dikaji menggunakan teori literary tourism.

Fokus kajian literary tourism ialah festival sastra, fenomena karya sastra, sastrawan, dan cerita rakyat yang berkontribusi dalam pengembangan dunia pariwisata. Selain itu, pembahasan juga mencakup bagaimana sastra menyampaikan kritik atas pembangunan pariwisata yang berlebihan (Putra 2019: 175-180). Pendekatan sastra pariwisata dapat dilakukan dalam empat area, yaitu kajian tematik pariwisata sastra (tourism themes), kajian atas peninggalan sastrawan dan tempat-tempat yang menjadi daya tarik wisata (literary figure, literary place), kajian 
aktivitas sastra seperti festival (literary events, activities), dan alihwahana sastra menjadi film untuk promosi wisata (Hoppen Brown, \& Fyall 2014: 39-40; Putra 2019:175-180). Berpijak pada konsep folklor dan literary tourism, penelitian ini berfokus untuk mengeksplorasi folklor Kampung Pitu Nglanggeran sebagai ikon pariwisata setempat.

\section{Metode}

Penelitian ini merupakan penelitian deskriptif kualitatif. Metode kualitatif ialah prosedur penelitian yang menghasilkan data deskripsi berupa kata-kata tertulis atau lisan dari orang-orang dan perilaku yang diamati (Moleong 2014: 5). Sumber data penelitian ini adalah narasumber (juru kunci dan pengelola wisata) dan cerita rakyat yang berkembang di Kampung Pitu. Data dalam penelitian ini berupa kata, kalimat, dan wacana dalam cerita rakyat Kampung Pitu yang memuat informasi tentang objek penelitian. Teknik pengumpulan data menggunakan wawancara, observasi, dan dokumentasi.

Analisis data dilakukan secara etnografi (Cresswell 2011) dengan modifikasi tahapan: (1) pemilihan ruang lingkup penelitian, (2) pengajuan pertanyaan meliputi deskripsi konteks, analisis tema-tema, dan interpretasi perilaku kultural masyarakat, (3) pengumpulan data etnografi, (4) analisis data etnografi, dan (5) menarik simpulan.

\section{Hasil dan Pembahasan}

\subsection{Cerita Rakyat di Kampung Pitu Nglanggeran}

Berdasarkan hasil wawancara dan observasi, ada tiga cerita rakyat yang berkembang di Kampung Pitu, Nglanggeran, yaitu Asal-Usul Kampung Pitu, Telaga Guyangan dan Rasulan. Berikut klasifikasi jenis-jenis cerita rakyat yang ada di Kampung Pitu.
Tabel 1

Klasifikasi Cerita Rakyat

\begin{tabular}{|c|c|c|c|}
\hline No. & $\begin{array}{l}\text { Judul } \\
\text { Cerita }\end{array}$ & Jenis & Keterangan \\
\hline & $\begin{array}{l}\text { Asal-Usul } \\
\text { Kampung } \\
\text { Pitu }\end{array}$ & $\begin{array}{l}\text { Le- } \\
\text { gen- } \\
\text { da }\end{array}$ & $\begin{array}{l}\text { Prosa ini berceri- } \\
\text { ta tentang asal } \\
\text { mula Kampung } \\
\text { Pitu Nglangge- } \\
\text { ran. Masyarakat } \\
\text { setempat per- } \\
\text { caya bahwa } \\
\text { Kampung Pitu } \\
\text { Nglanggeran } \\
\text { bermula dari } \\
\text { kisah Eyang Iro } \\
\text { Kromo dan pu- } \\
\text { saka dalam po- } \\
\text { hon Kinah Ga- } \\
\text { dung Wu-lung. } \\
\text { Tokoh dalam } \\
\text { cerita ini adalah } \\
\text { manusia, se- } \\
\text { dangkan tempat } \\
\text { terjadinya di } \\
\text { Kampung Pitu } \\
\text { Nglanggeran. } \\
\text { Dengan demi- } \\
\text { kian, prosa ini } \\
\text { dapat diklasifi- } \\
\text { kasikan sebagai } \\
\text { legenda. }\end{array}$ \\
\hline & $\begin{array}{l}\text { Telaga } \\
\text { Guyangan }\end{array}$ & Mite & $\begin{array}{l}\text { Prosa ini berceri- } \\
\text { ta tentang se- } \\
\text { buah mata air } \\
\text { yang suci. Ko- } \\
\text { non, tempat ini } \\
\text { sering diguna- } \\
\text { kan para bida- } \\
\text { dari dan kuda } \\
\text { saktinya untuk } \\
\text { mandi. Sampai }\end{array}$ \\
\hline
\end{tabular}




\begin{tabular}{|c|c|c|c|}
\hline No. & $\begin{array}{l}\text { Judul } \\
\text { Cerita }\end{array}$ & Jenis & Keterangan \\
\hline & Rasulan & Mite & $\begin{array}{l}\text { saat ini, air di } \\
\text { telaga ini diper- } \\
\text { caya dapat } \\
\text { membuat awet } \\
\text { muda. Cerita ini } \\
\text { dianggap benar- } \\
\text { benar terjadi dan } \\
\text { diangggap suci } \\
\text { oleh masyara- } \\
\text { kat. Tokoh da- } \\
\text { lam cerita ini } \\
\text { yaitu para bida- } \\
\text { dari. Dengan } \\
\text { demikian, prosa } \\
\text { ini dapat diklasi- } \\
\text { fikasikan seba- } \\
\text { gai mite. } \\
\text { Prosa ini berceri- } \\
\text { ta tentang tradisi } \\
\text { upacara adat } \\
\text { yang dipercaya } \\
\text { masyarakat da- } \\
\text { pat menjaga } \\
\text { kemakmuran, } \\
\text { kesejahteraan, } \\
\text { dan keamanan } \\
\text { warga setempat. } \\
\text { Prosa ini juga } \\
\text { berkaitan den- } \\
\text { gan cerita Dewi } \\
\text { Sri yang diang- } \\
\text { gap sebagai de- } \\
\text { wi padi. Cerita } \\
\text { ini dianggap be- } \\
\text { nar oleh masya- } \\
\text { rakat sehingga } \\
\text { dapat diklasifi- }\end{array}$ \\
\hline
\end{tabular}

Asal-Usul Kampung Pitu Nglanggeran termasuk dalam kategori cerita rakyat legenda. Legenda ini berisi rincian kisah keberadaan Kampung Pitu Nglanggeran sejak zaman dahulu hingga sekarang. Dahulu, kampung ini dijuluki sebagai Desa Telaga Planggeran. Telaga di desa ini tidak pernah mengering meski musim kemarau melanda. Warga desa setempat percaya bahwa air telaga ini sangat suci. Konon, telaga ini kerap digunakan untuk guyang (memandikan) kuda sembrani sehingga sering disebut dengan Telaga Guyangan. Suatu ketika utusan abdi dalem kraton datang ke Kawasan Desa Telaga Planggeran. Utusan abdi dalem ini mengetahui bahwa desa tersebut memiliki pohon Kinah Gadung Wulung. Pohon ini berisi sebuah pusaka langka. Lantas, utusan abdi dalem membuat sayembara: "Barang siapa yang bisa merawat benda pusaka tersebut maka akan diberi tanah secukupnya di daerah itu untuk peng-hidupannya beserta anak cucu keturunanya."

Berpuluh-puluh orang mencoba peruntungan. Namun, tidak ada satu pun yang betah dan tinggal di kawasan tersebut. Hanya Eyang Iro Kromo yang berhasil menjaga pusaka tersebut. Akhirnya, Eyang Iro Kromo pun diberi izin oleh kraton untuk tinggal di kawasan itu. Keturunan Eyang Iro Kromolah yang sampai saat ini masih tinggal Kampung Pitu. Masyarakat yang tinggal di kampung itu hanya berjumlah tujuh kepala keluarga. Sempat beberapa kali menjadi dua belas kepala keluarga, sembilan kepala keluarga, tetapi karena berbagai hal secara alamiah kembali menjadi tujuh kepala keluarga. Jumlah tujuh kepala keluarga di Kampung Pitu masih bertahan hingga saat ini. Perkembangan wisata Desa Nglanggeran memengaruhi eksistensi Desa Telaga Planggeran. Akhirnya, Desa Telaga Planggeran sering disebut sebagai Kampung Pitu Nglanggeran karena warga yang tinggal di kampung tersebut berjumlah tujuh kepala keluarga. 
Berdasarkan klasifikasi cerita rakyat menurut Bascom, Asal-Usul Kampung Pitu Nglanggeran termasuk dalam kategori legenda, yaitu prosa rakyat yang dianggap pernah benar-benar terjadi, tetapi tidak dianggap suci. Legenda ditokohi oleh manusia. Biasanya legenda berkaitan cerita di balik sebuah tempat (Bascom 1965: 3-5; Efirson 2017: 2). Keberadaan tokoh Eyang Iro Kromo dalam cerita dan penjelasan rinci tentang asal mula nama Kampung Pitu Nglanggeran menjadi indikasi kuat bahwa cerita ini masuk dalam klasifikasi legenda.

Telaga Guyangan termasuk dalam kategori cerita rakyat mite. Mite ini menceritakan tentang para bidadari yang sering singgah ke Kampung Pitu beserta kuda sembrani tunggangan sang bidadari. Kampung Pitu dipercaya penuh berkah dan bertuah. Kampung ini memiliki telaga yang tidak pernah kering meski musim kemarau panjang. Konon, telaga ini sering digunakan untuk mandi para bidadari. Peristiwa ini biasanya terjadi pada malam Selasa Kliwon atau Jumat Kliwon ketika bulan purnama. Tujuh bidadari turun dari kayangan mengendarai kuda sembrani. Para bidadari kemudian mandi di telaga tersebut, sedangkan kuda sembrani menunggu di samping telaga. Terkadang, kuda sembrani pun dimandikan di telaga tersebut. Masyarakat setempat memercayai bahwa "Platarane watu lintang, sing nyirami nabi, sing ngosoki para wali, sumure ndara tundha, banyune saking talang kencana, sing duwe banyu Kang Maha Kuwasa."

Tempat pemberhentian kuda sembrani ini meninggalkan jejak di batu. Jejak ini sering diambil oleh abdi dalem kraton dengan mantra tertentu. Masyarakat di sekitar percaya bahwa telaga merupakan mata air suci. Kemudian, muncul kepercayaan bahwa barang siapa yang membasuh muka menggunakan air telaga ini maka akan awet muda. Saat ini, telaga guyangan beralih fungsi men- jadi sawah. Tinggal tersisa sumber mata air kecil di samping telaga.

Fokus cerita Telaga Guyangan ini adalah keajaiban para bidadari dan kuda sembrani yang dipercaya masyarakat. Hal ini sesuai dengan teori mite yang dianggap benarbenar terjadi serta dianggap suci oleh yang empunya cerita. Mite ditokohi oleh para dewa atau makhluk setengah dewa (Bascom 1965: 3-5; Efirson 2017: 2). Tokoh utama dalam cerita tersebut ialah para bidadari dan kuda sembrani yang dianggap memiliki kekuatan magis. Oleh karena itu, hal ini menjadi ciri bahwa Telaga Guyangan masuk dalam kategori mite.

Rasulan termasuk dalam kategori mite. Rasulan adalah tradisi turun-temurun yang tidak pernah ditinggalkan warga Kampung Pitu. Warga percaya bahwa Rasulan mencegah terjadinya berbagai bencana. Rasulan sebagai wujud ucapan rasa syukur masyarakat atas panen yang melimpah. Masyarakat Kampung Pitu memahami bahwa hasil panen itu diperoleh karena adanya peranan Dewi Sri yang dianggap dewi padi. Selain mela-kukan sedekah bumi, warga juga menggelar acara kesenian. Kesenian yang dilestarikan masyarakat setempat adalah tari tayub/ledek. Tarian ini digelar di dekat sumber Telaga Guyangan. Ada empat tembang yang harus dinyanyikan, yaitu blendrong, ijo-ijo, eling-eling, dan sri slamet.

Ada satu pantangan yang tidak boleh dilanggar masyarakat setempat, yaitu menggelar pertunjukan wayang, apalagi dengan lakon Raden Ongko Wijaya. Dahulu, Kampung Pitu disebut pula sebagai Gunung Wayang. Para sesepuh percaya bahwa semua tokoh wayang berada di Kampung Pitu. Oleh karena itu, warga setempat dilarang menggelar pertunjukkan wayang. Warga percaya jika pantangan ini dilanggar akan terjadi marabahaya.

Cerita di balik tradisi rasulan ini terfokus pada tokoh Dewi Sri, Raden Ongko Wijaya, 
dan beberapa tokoh wayang. Dewi Sri menjadi simbol keberhasilan panen dan kemakmuran masyarakat setempat, sedangkan Raden Ongko Wijaya beserta tokoh wayang lain sebagai pengingat ketentraman masyarakat. Oleh karena itu, cerita rasulan ini termasuk dalam kategori mite.

Berdasarkan hasil dan pembahasan, dapat disimpulkan bahwa cerita rakyat di Kampung Pitu Nglanggeran didominasi oleh mite. Hanya ada satu legenda yang berkembang di kampung tersebut, yaitu Asal-Usul Kampung Pitu Nglanggeran. Cerita rakyat yang lain termasuk dalam klasifikasi mite. Masyarakat Kampung Pitu Nglanggeran masih memercayai legenda dan mite yang berkembang di sekelilingnya.

\subsection{Cerita Rakyat sebagai Basis Pariwisata}

Cerita rakyat dapat berfungsi sebagai basis pengembangan pariwisata di suatu daerah. Kearifan lokal, termasuk cerita rakyat yang dimiliki masyarakat di Kawasan Ekowisata Gunung Api Purba Nglanggeran berpotensi meningkatkan daya tarik wisata. Kampung Pitu Nglanggeran menarik wisatawan dari segi wisata budaya, tetapi potensinya belum digarap secara maksimal. Berikut pemetaan daya tarik wisata berdasarkan cerita rakyat di Kampung Pitu.

Tabel 2

Pemetaan Daya Tarik Wisata Berdasarkan Cerita Rakyat

\begin{tabular}{llc}
\hline No. & Judul Cerita & Daya Tarik \\
\hline Asal-Usul & • Aturan/ hukum: la- \\
Kampung & Pi- & rangan Kampung \\
tu & & Pitu dihuni oleh le- \\
& bih dari tujuh kepa- \\
& la keluarga. \\
& & Legenda: Kampung \\
\hline
\end{tabular}

\begin{tabular}{|c|c|}
\hline No. Judul Cerita & Daya Tarik \\
\hline \multirow{3}{*}{$\begin{array}{l}\text { Telaga } \\
\text { Guyangan }\end{array}$} & Pitu \\
\hline & $\begin{array}{l}\text { - Kepercayaan: Air } \\
\text { dari Telaga Guyan- } \\
\text { gan dipercaya da- } \\
\text { pat membuat awet } \\
\text { muda. }\end{array}$ \\
\hline & $\begin{array}{l}\text { - Mite: cerita para bi- } \\
\text { dadari dan kuda } \\
\text { sembrani. }\end{array}$ \\
\hline \multirow[t]{3}{*}{ Rasulan } & $\begin{array}{l}\text { - Ritual: Upacara } \\
\text { adat rasulan, per- } \\
\text { tunjukkan le- } \\
\text { dek/tayub. }\end{array}$ \\
\hline & - Mite: Dewi Sri \\
\hline & $\begin{array}{l}\text { - Aturan/hukum: la- } \\
\text { rangan menggelar } \\
\text { pertunjukkan } \\
\text { wayang terutama } \\
\text { dengan lakon Ra- } \\
\text { den Ongko Wijaya } \\
\text { di Kampung Pitu. }\end{array}$ \\
\hline
\end{tabular}

(Sugiarto \& Palupiningsih 2019: 41-50)

Pemetaan daya tarik wisata berdasarkan cerita rakyat ini dapat dikaji menggunakan pendekatan literary tourism (sastra pariwisata). Pendekatan sastra pariwisata dapat dilakukan dalam empat area, yaitu (1) kajian tematik pariwisata sastra (tourism themes), (2) kajian atas peninggalan sastrawan dan tempat-tempat yang menjadi daya tarik wisata (literary figure, literary place), (3) kajian aktivitas sastra seperti festival (literary events, activities), dan (4) kajian sastra yang dialihwahanakan dalam bentuk lain seperti film dan menjadi sarana promosi wisata (Hoppen et al. 2014: 39-40; Putra 2019: 175). Berikut gambaran cerita rakyat di Kampung 
Pitu Nglanggeran yang dapat dijadikan basis pengembangan pariwisata.

\subsubsection{Legenda Kampung Pitu: Literary Place} Legenda Kampung Pitu Nglanggeran menjadi ikon unik Kawasan Ekowisata Desa Nglanggeran. Selain destinasi alam, aturan/hukum jumlah kepala keluarga menjadi keunikan tersendiri. Sejak zaman dahulu, kampung ini hanya memiliki tujuh kepala keluarga dan masih terjaga hingga saat ini. Keunikan ini dapat dijadikan sebagai landasan pengembangan wisata berbasis literary place (Pratiwi \& Pinasti 2017: 2; Saputra 2017: $3)$.

Potensi alam berupa spot sunrise, sunset, outbond, tracking, dan camping dapat mendukung potensi budaya dan adat yang berlaku. Hal ini menjadi wisata berbasis legenda, seperti wisata di beberapa daerah Indonesia. Gunung Tangkuban Perahu merupakan ikon wisata di Lembang, Jawa Barat yang didongkrak oleh cerita rakyat (Aditya 2019). Cerita rakyat Sangkuriang dipercaya ma-syarakat sebagai asal mula nama Tangkuban Perahu. Cerita inilah yang kemudian mengangkat Tangkuban Perahu sebagai salah satu destinasi wisata populer. Pantai Bandengan, Jepara juga merupakan produk wisata dari popularitas legenda Teluk Awar yang berkembang di daerah setempat (Harsono 2017: 1-7). Destinasi wisata Pantai Air Manis (Sumatera Barat) didukung oleh cerita rak-yat Malin Kundang. Legenda yang menjadi me-mori kolektif masyarakat Sumatera Barat ini kemudian disematkan pada wisata Pantai Air Manis. Keberadaan patung Malin Kundang yang sering disebut kaba menjadi daya tarik wisatawan (Susilastri 2019). Ada pula destinasi wisata di Kota Palembang, yaitu Pulau Kemaro. Destinasi wisata ini lekat dengan Legenda Pulau Kemaro bermula dari kisah cinta Pangeran Tan Bun An dan Putri Siti Fatimah. Destinasi wisata ini populer di kalangan masyarakat dengan klenteng dan pohon cinta sebagai simbol kesetiaan kisah cinta.

Wang Zengqi Water Region Folk-custom Theme Park Jieshou, China juga mengangkat cerita kehidupan lama di wilayah peraiaran Gaoyou. Kisah utama cerita ini menggambarkan orang-orang biasa dalam mencari kebenaran, kebaikan, dan keindahan hidup. Wisatawan dapat menikmati wisata di alam terbuka dengan latar belakang kehidupan masa lampau (Jia 2009: 69-83). Destinasi wisata di Three Gorges dan The Yangtze River China juga mengangkat sejarah dan budaya setempat. Legenda ini diperoleh dari puisi klasik budaya China. Legenda ini digunakan untuk menarik antusias wisata dengan cara dialog budaya (Yu \& Xu 2016: 393-403). Berbagai destinasi wisata populer yang dikembangkan berdasarkan legenda membuktikan bahwa legenda dapat menyokong wisata di suatu daerah.

\subsubsection{Mite Telaga Guyangan dan Rasulan: Literary Activities}

Mite tentang Telaga Guyangan dan Rasulan berpotensi dijadikan landasan pengembangan pariwisata. Daya tarik dari mite Telaga Guyangan ialah tokoh para bidadari, kuda sembrani dan air telaga yang diyakini dapat membuat awet muda. Ketiga hal ini dapat digunakan untuk mendongkrak popularitas wisata Kampung Pitu. Mite tentang Rasulan yang berkaitan dengan Dewi Sri dapat menjadi pendongkrak utama wisata Kampung Pitu. Mite rasulan memiliki berbagai daya tarik, seperti upacara adat dan pertunjukkan ledek/tayub. Jika dikelola dengan baik, daya tarik ini dapat diolah menjadi aktivitas terpadu yang menarik wisatawan.

Kolam peri Isle of Skye-Fairy Pools di Skotlandia merupakan destinasi wisata internasional yang berkembang karena mite peri kolam (Farhan 2016; Ironside \& Massie 2020: 1-18). Kolam ini memiliki pemandangan dan air yang jernih sehingga wisatawan banyak 
berdatangan. Masyarakat Isle of Sky sendiri memercayai beberapa mitos peri, yaitu peri lembah (fairy glen), peri bukit batu (fairy knoll), dan peri jembatan (fairy bridge) (Ironside \& Massie 2020: 1-18). Selain itu, banyak pula destinasi wisata Indonesia yang menjadikan mite sebagai bagian daya tarik seperti epos Ramayana dan Mahabarata yang diangkat sebagai lakon seni pertunjukkan Tari Kecak dan cerita Calon Arang yang diadopsi ke dalam pertunjukkan Tari Barong (Putra 2019: 180).

Ada juga ritual tradisi yang hampir mirip dengan Rasulan di Kampung Pitu, yaitu Pesta Lomban di Jepara, Jawa Tengah. Upacara ini dilakukan oleh para nelayan di Jepara. Rasa bahagia menyambut idul fitri diwujudkan dalam bentuk sedekah laut yang kemudian disebut Pesta Lomban. Ada satu prosesi yang unik, yaitu Perang Teluk. Para nelayan dari masing-masing kapal langsung menyerang kapal-kapal lainnya dengan melemparkan kupat, kolang-kaling, telur, dan lepet ke perahu lainnya. Upacara adat ini menarik ba-nyak pengunjung, termasuk wisatawan. Antusiasme masyarakat yang mendasari pemerintah membuat Festival Pesta Lomban (Pertiwi 2012; Putra 2019: 173-181; Rasyid 2020). Selain festival tersebut, Jepara juga berhasil mengangkat ritual perang obor menjadi Festival Obor. Ritual ini disebut pula sebagai sedekah bumi untuk menghindarkan desa dari segala bala. Kedua festival ini membuktikan bahwa cerita rakyat yang digarap secara kolaboratif dapat mengangkat potensi wisata di daerah setempat.

Cerita rakyat lain yang digarap menjadi festival bertaraf internasional, yaitu Sri Tanjung, Banyuwangi, Jawa Timur. Cerita ini diangkat menjadi tema festival bertaraf internasional Banyuwangi Ethno Carnival (BEC) pada tahun 2016. BEC sendiri mengangkat tema ritual, tradisi, legenda, dan mite yang berbeda di tiap tahun. BEC menyajikan berbagai petunjukkan sekaligus memamerkan berba- gai cendera mata, cerita rakyat, destinasi wisata, dan dokumen kebudayaan daerah Banyuwangi. Festival ini berhasil mengangkat kebudayaan daerah, termasuk cerita rakyat Banyuwangi (Anoegrajekti \& Imawati 2020).

Potensi mite, upacara adat, dan ritual yang ada di Kampung Pitu Nglanggeran sangat berpotensi dijadikan sebuah aktivitas besar seperti festival. Rekomendasi lain yang dapat dilakukan adalah mengelola sistem pertunjukkan budaya yang memadukan berbagai unsur. Dengan demikian, potensi cerita rakyat di Kampung Pitu Nglanggeran menjadi optimal untuk menyokong pariwisata.

\subsubsection{Cerita Rakyat sebagai Tourism Branding}

Pariwisata dan budaya adalah dua hal berbeda, tetapi dapat dikaitkan dan berjalan berdampingan. Cerita rakyat merupakan salah satu bentuk budaya otentik masyarakat. Cerita rakyat berupa legenda, mite, dan dongeng dapat digali secara mendalam sehingga berpotensi dijadikan branding atau ikon sebuah destinasi wisata (Endriani 2015: 43-56; Putra 2019: 173-181).

Sesuai paparan subbab sebelumnya, cerita rakyat dapat menjadi landasan pengembangan pariwisata di suatu daerah. Kegiatan kepariwisataan dapat disokong oleh kajian karya sastra sebagai media promosi atau branding. Suatu resor wisata membutuhkan brand untuk menghadapi persaingan. Brand memiliki arti tidak sebatas slogan, tagline, dan logo. Akan tetapi, brand harus mencakup keseluruhan destinasi wisata yang di dalamnya terdapat nilai, filosofi, budaya, dan harapan masyarakat untuk destinasi tersebut (Bungin \& Kencana 2017; Suyasa 2019: 526). Branding dapat dilihat dari aspek kesadaran (awareness), asosiasi (association), kualitas yang dipersepsikan (perceived quality), kepercayaan (trust), dan loyalitas (loyality).

Ada beberapa daerah yang menjadikan cerita rakyat sebagai branding pariwisata se- 
tempat. Misalnya, situs kawasan wisata Danau Toba (Sumatera Utara) yang populer karena legenda Danau Toba. Destinasi wisata Tangkuban Perahu, Bandung yang populer dengan branding kisah cinta Dayang Sumbi dan Sangkuriang. Legenda ini sudah bertransformasi berkali-kali, salah satunya film Dayang Sumbi dan Sangkuriang yang diperankan oleh Suzanna dan Clift Sangra pada tahun 1980-an. Kepopuleran legenda ini mampu mendongkrak popularitas tujuan wisata dan mendorong minat masyarakat untuk berkunjung ke lokasi tersebut (Sunarti 2020). Ada pula destinasi wisata Pulo Kemaro di Palembang yang populer karena legenda kisah cinta Siti Fatimah dan Tan Bun An. Berdasarkan hasil riset (Ratnawati \& Nurhayati (2020), wisatawan tertarik berkunjung ke Pulo Kemaro karena mengetahui legenda yang berkaitan dengan objek wisata. Branding Pulo Kemaro digencarkan melalui media sosial dan Youtube yang mempertunjukkan legenda dalam versi drama, vlog, film pendek, dan puisi. Wisa-tawan yang berkunjung dimanjakan dengan kein-dahan alam sekaligus disuguhi pertunjukkan le-genda Pulo Kemaro dalam bentuk tarian, sendratari, atau teater.

Ada kawasan resort yang terkenal di Lombok, yaitu Resort Putri Mandalika. Kawasan wisata ini terkenal dengan keindahan resort dan Festival Nyale (Suyasa 2019: 526533). Kawasan ini populer dan berkembang karena Legenda Putri Mandalika yang bertautan dengan lokasi tersebut. Untuk menghadapi persaingan dunia pariwisata, pengelola resor mengusung brand Kuta Mandalika wisata selatan Lombok. Nama Kuta kebetulan sama dengan objek wisata terkenal di Bali, sedangkan resor ini kebetulan lokasinya di Desa Kuta. Dengan demikian, pengelola memberi nama Kuta Mandalika mengingat kata kuta sudah dikenal luas di dunia pariwisata; dan pantainya tidak kalah menarik dengan Kuta Bali. Daya tarik lain resor ini ialah Festival Bau Nyale yang diambil dari rang- kaian ritual cerita Putri Mandalika. Jadi, dapat disimpulkan bahwa Mandalika sebagai branding resor wisata Pantai Selatan telah menjadi identitas sebuah tempat. Akhirnya, resor wisata ini indentik dengan atraksi wisata dan Festival Bau Nyale yang mengandung nilai filosofis tertentu. Resor ini menjadi simbol menyatunya alam dan cerita Putri Mandalika yang menjiwai suatu tempat.

Pemaparan itu menunjukkan bahwa cerita rakyat dapat dijadikan branding tourism sebuah destinasi wisata. Artinya, cerita rakyat yang berkembang di Kampung Pitu Nglanggeran berpotensi untuk menjadi branding kawasan wisata Nglanggeran. Berdasarkan hasil wawancara dengan pengelola wisata Kampung Pitu, wisa-tawan yang berkunjung biasanya penasaran karena aturan/hukum jumlah kepala keluarga di Kampung Pitu. Artinya, Legenda Asal-Usul Kampung Pitu Nglanggeran dapat menjadi branding utama wisata ini. Brand ini tentu harus didukung oleh metamorfosis legenda menjadi pertunjukan teater, sendratari, film pendek, cerita rakyat, atau bentuk narasi lain yang dapat digunakan sebagai promosi. Dengan demikian, Kampung Pitu Nglanggeran dapat menjadi destinasi wisata dengan brand yang mengusung nuansa dan nilai-nilai mitologis cerita rakyat setempat.

\section{Simpulan}

Kampung Pitu Nglanggeran, Gunungkidul, Daerah Istimewa Yogyakarta memiliki beberapa cerita rakyat yang dapat menjadi landasan pengembangan pariwisata. Berdasarkan hasil pembahasan, cerita rakyat yang berkembang di Kampung Pitu terdiri atas Legenda Asal-Usul Kampung Pitu, mite Telaga Guyangan, dan mite Rasulan. Masing-masing cerita memiliki daya tarik tersendiri.

Legenda Asal-Usul Kampung Pitu memiliki daya tarik dalam hal cerita dan aturan/hukum pada jumlah kepala keluarga yang bertempat tinggal. Mite Telaga Guyan- 
gan memiliki daya tarik dalam hal kepercayaan kekuatan magis air telaga dan cerita para bidadari beserta kuda sembrani. Mite Rasulan memiliki daya tarik dalam hal upacara adat rasulan, pertunjukkan ledek/tayub, mite Dewi Sri, dan aturan/hukum larangan mementaskan wa-yang dengan lakon Raden Ongko Wijaya.

Cerita rakyat dapat dijadikan branding tourism sebuah destinasi wisata. Cerita rakyat yang berkembang di Kampung Pitu Nglanggeran berpotensi untuk menjadi branding kawasan Nglanggeran. Wisatawan biasanya penasaran karena aturan/hukum jumlah kepala keluarga yang terdapat di Kampung Pitu. Artinya, Legenda Asal-Usul Kampung Pitu Nglanggeran dapat menjadi branding utama wisata ini. Branding perlu didukung dengan metamorfosis cerita rakyat menjadi pertunjukkan teater, sendratari, film pendek, buku cerita rakyat, atau bentuk narasi lain yang dapat digunakan sebagai promosi.

\section{Daftar Pustaka}

Adhi, K. 2019. Lagu Banyu Langit Karya Didi Kempot Dianggap Bantu Promosikan Wisata Nglanggeran. Pidjar, September 1.

Aditya, R. 2019. Gunung Tangkuban Perahu, Legenda Sangkuriang dan Wisatanya. Suara.

https:// www.suara.com/lifestyle/2 020/12/19/142839/gunung-

tangkuban-perahu-legendasangkuriang-danwisatanya?page=all

Agmasari, Silvita. 2019. Apa Itu 10 Destinasi Wisata Prioritas? Tugas Lama Untuk Wishnutama. Kompas.Com. https:/ / travel.kompas.com/read/2 019/10/23/104726127/apa-itu-10destinasi-wisata-prioritas-tugas- lama-untuk-wishnutama?page=all

Amanat, Tri. 2019. Strategi Pengembangan Destinasi Wisata Berbasis Folklor (Ziarah Mitos: Lahan Baru Pariwisata Indonesia). Jurnal Pariwisata Terapan 3(1):65. https:/ / doi.org/10.22146/jpt.49277

Anoegrajekti, Novi, and Endah Imawati. 2020. Sastra Pariwisata: Dari Legenda Sampai Banyuwangi Ethno Carnival. Yogyakarta: PT. Kanisius.

Bascom, William. 1965. The Forms of Folklore: Prose Narratives. Journal of American Folklore, 78(307):3-20. https:/ / doi.org/10.2307/538099

Bungin, Burhan, and Kencana. 2017. Komunikasi Pariwisara (Tourism Communication) Pemasaran Dan Brand Destinasi. Jakarta: Prenada Media Group.

DIY, Dinas Pariwisata. 2020. Menyusuri Mitos Kampung Pitu Di Nglanggeran. Retrieved (https://visitingjogja.com/28944/m enyusuri-mitos-kampung-pitu-dinglanggeran/).

Efirson. 2017. Analisis Cerita Tupai Janjang: Teori Fungsi William R. Bascom. Ceudah 7(1):1-11.

Endriani, Deni. 2015. Making a Tourism Icon: The Valorization of Siti Nurbaya Bridge in West Sumatera. Jurnal Master Pariwisata (JUMPA) 1(August 2001):43-56. https:/ / doi.org/10.24843/JUMPA.2 015.v01.i02.p04

Farhan, A. 2016. Mengintip Kolam Peri Di 
Skotlandia. Detik, February 1. https://travel.detik.com/internatio nal-destination/d-

3131493/mengintip-kolam-peri-diskotlandia

Gunungkidul, Dinas Pariwisata Kabupaten. 2020. Gunung Api Purba Nglanggeran. Retrieved (https:/ / wisata.gunungkidulkab.go. id/2020/07/09/nglanggeran-2/).

Harsono, Siswo. 2017. Folklore Tourism in Jepara. Culturalistics: Journal of Cultural, Literary, and Linguistic Studies 1(1):1-7.

Hidayat, R. 2019. Banyu Langit Didi Kempot Bikin Ngetop Situs Geopark Ini. Pidjar. https://www.gatra.com/detail/ne ws/438795/gaya \%20hidup/banyulangit-didi-kempot-bikin-ngetopsitus-geopark-ini

Hoppen, Anne, Lorraine Brown, and Alan Fyall. 2014. Literary Tourism: Opportunities and Challenges for the Marketing and Branding of Destinations. Journal of Destination Marketing and Management 3(1):37-47.

https://doi.org/10.1016/j.jdmm.201 3.12.009

Ironside, Rachael, and Stewart Massie. 2020. The Folklore-Centric Gaze: A Relational Approach to Landscape, Folklore and Tourism. Time and Mind 00(00):1-18.

https:/ / doi.org/10.1080/1751696X. 2020.1809862

Jia, Hongyan. 2009. The Construction of Literary Tourism Site. Tourism 57(1):69-83.
Miles \& Huberman. 1994. An Expanded Sourcebook: Qualitative Data Analysis. London: Sage Publications.

Moleong, Lexy. 2014. Metode Penelitian Kualitatif. Bandung: PT Remaja Rosdakarya.

Pertiwi, N. L. .. 2012. Jangan Lewatkan Perang Obor Di Jepara. Kompas, April 28. https:/ / nasional.kompas.com/ read /2012/04/28/12024923/ Travel Tr avel\%20Story

Pratiwi, Beta Desi, \& Indah Pinasti. 2017. Pariwisata dan Budaya (Studi Peran Serta Masyarakat Lokal Dalam Pengelolaan Pariwisata di Kampung Pitu, Nglanggeran, Patuk, Gunungkidul). Journal Student Uny 6(8). http:/ / library.fis.uny.ac.id/opac/in dex.php? $p=$ show_detail\&id $=7244$

Putra, I Nyoman Darma. 2019a. Sastra Pariwisata: Pendekatan Interdisipliner Kajian Sastra Dan Pariwisata. EProceeding Seminar Nasional INOBALI, 2019 173-81.

Putra, I Nyoman Darma. 2019b. Sastra Pariwisata: Pendekatan Interdisipliner Kajian Sastra Dan Pariwisata. Seminar Nasional Inovasi Baru Dalam Penelitian Sains, Teknologi, dan Humaniora (2005):173-81.

Putra, I Nyoman Darmaputra. 2019. Sastra Pariwisata: Pendekatan Interdisipliner Kajian Sastra Dan Pariwisata. EProceeding Seminar Nasional INOBALI, 2019 173-81.

Rasyid, S. 2020. Tradisi Unik Masyarakat 
Nelayan Jepara Saat Syawal, Pesta Lomban. Merdeka, May 25. https://www.merdeka.com/jateng /tradisi-unik-masyarakat-nelayanjepara-saat-syawal-pestalomban.html

Ratnawati, and Nurhayati. 2020. Legenda Pulo Kemaro: Pengalihwahanaannya Bagi Kemajuan Objek Wisata. Yogyakarta: PT. Kanisius.

Saputra, Eryd. 2017. Kode Etik Wisatawan Dalam Menunjang Kelestarian Gunung Api Purba Nglanggeran. Jurnal Pariwisata Pesona, 2(2):1-10. https://doi.org/10.26905/jpp.v2i2.1 657

Sugiarto, Eko, \& Angesti Palupiningsih. 2019. Identifikasi Kearifan Lokal Sebagai Upaya Untuk Meningkatkan Daya Tarik Wisata Di Kawasan Ekowisata Gunung Api Purba Nglanggeran, Kecamatan Patuk, Kabupaten Gunungkidul. Kepariwisataan Jurnal Ilmiah 13(2). http:/ / ejournal.stipram.ac.id/index .php/kepariwisataan/article/view/ 48.

https:/ / doi.org/10.47256/kepariwi sataan.v13i02.48

Sunarti, S. 2020. Pemberdayaan Cerita Rakyat Untuk Pengembangan Destinasi Wisata Yang Berbasis Kekayaan Budaya Indonesia. Yogyakarta: PT. Kanisius.
Suyasa. 2019. Literature as a Tourism Attraction. Proceedings of the 28th International Conference on Literature: "Literature as a Source of Wisdom 1(1):526-33. doi: https://doi.org/10.24815/.v1i1.1450 1.

Taufiq, Ahmad, and Siswanto. 2019. Van Der Wijck's Trace In Pantura: The Development of Tourism Industry Based On Literary-Culture Site. Proceedings of the 28th International Conference on Literature: "Literature as a Source of Wisdom, July 11-13, 2019, Universitas Syiah Kuala, Banda Aceh, Indonesia 169-75. doi: DOI: 10.24815/.v1i1.14414.

Yu, Xiaojuan, and Honggang Xu. 2016. Ancient Poetry in Contemporary Chinese Tourism. Tourism Management 54:393-403. d https:/ / doi.org/10.1016/j.tourman. 2015.12.007

Yuwono, M. 2019. Lagu Banyu Langit Didi Kempot, Bikin Turis Penasaran Ke Nglanggeran. Kompas.Com. Retrieved (https:/ / travel.kompas.com/read/2 019/08/29/151000827/lagu-banyulangit-didi-kempot-bikin-turispenasaran-kenglanggeran? page=all). 